\title{
The Implementation of Think Pair Share on Learning Outcomes and Self- Efficacy in Fourth Grade SD Muhammadiyah 12 Pamulang
}

\author{
Fidrayani, Novia Fauzia \\ Syarif Hidayatullah State Islamic University Jakarta, Jl. Ir. H. Djuanda 95, Ciputat, Indonesia \\ Corresponding e-mail: Fidrayani7276@uinjkt.ac.id
}

\begin{abstract}
This study aims to describe the improvement of learning outcomes and self-efficacy on thematic learning through the implementation of Think Pair Share learning strategy in fourth grade students at SD Muhammadiyah 12 Pamulang. The type of research used is qualitative with classroom action research which is carried out in two cycles. The subject of this research is the fourth grader of SD Muhammadiyah 12 Pamulang. Data collection techniques used was observations, tests, field notes, and documentation. Data analysis was done descriptively qualitative with flow method is data analyzed since learning action implemented and developed during learning process. The data was validated with source triangulation. The result of this research is 1) there is improvement of student learning result with student indicator that got value > KKM on thematic learning from the initial condition that is $64 \%$ to $90 \%$. 2) There is an increase in self- efficacy seen from academic self- efficacy, social self- efficacy and emotional self- efficacy by $10 \%$ from baseline conditions ie $80 \%$ to $90 \%$. Good time management should be consisidered to implementation TPS.
\end{abstract}

Keywords: Learning outcomes, self-efficacy, primary school

\section{INTRODUCTION}

Learning outcomes are various changes that occur in someone who performs learning activities, whether it's aspects of knowledge, attitude or skills. Knowledge is owned through activities of knowing, understanding, applying, analyzing, evaluating, and creating. At the primary school level students' knowledge is owned by knowing, understanding, and applying activities. Learning outcomes are a reference to see the success of learning. After doing the learning activities everyone would expect good learning outcomes. Thus, it can affect student selfefficacy. Self-efficacy is a strong belief based on our evaluation of various sources of information about our abilities. In other words, self-efficacy is a belief in one's own ability. Self-efficacy has a very important role, because efficacy serves to regulate emotional states and emotional reactions. When a person is faced with a difficult problem or task, the person's self-efficacy will determine how the person will act. People who have high confidence in their ability will always try to solve the problem because they have a strong commitment and never give up. People who doubt their ability will avoid the difficult tasks they perceive as personal threats. They have low aspirations and a weak commitment to achieve the goals set by them. When faced with a difficult task, they focus on their shortcomings, on the obstacles they face and all sorts of possible bad outcomes. They do not think how to succeed in doing so. They relax their efforts and quickly give up in the face of adversity. They are slow to restore a sense of accomplishment after feeling a failure or setback, as they regard satisfied with their inefficient work as a deficiency. They do not want failure to get maximum results because they are afraid of losing confidence in their abilities. They will become stress-free and depressed individuals.

To be able to rise from failure requires a high self-efficacy. Self-efficacy is a belief that in a person's ability to do something. Bandura states that the high and low self-efficacy of a person is influenced by four things, namely: First, the experience of success in the previous task; Second, seeing others succeeds in performing a task; Third, encouragement from others who encourage us (motivation or praise); Fourth, the level of physiological stimulation. The development of selfefficacy in children aged 4-6 years has high selfefficacy, they are quite confident in their ability to 
perform various tasks and in fact they overestimate what they can do. While in elementary school age children, their self-efficacy began to decline, this is because elementary school children are better able to remember their successes and failures in the past, they also have been able to compare how their performance with peers. As a result of these changes, they become less convinced of what they can do and what they do not. Sehigga children at elementary school need help in order to succeed in various tasks to improve self-efficacy because of the low self-efficacy of a person is certainly very influential on the actions that someone will take when facing something. Bandura also explains that self-efficacy determines whether a person will exhibit certain behaviors as strongly as a person can survive in the face of adversity or failure, and how success or failure in a particular task affects a person's future behavior.

Based on preliminary study and observation conducted in fourth grade of SD Muhammadiyah 12 Pamulang, Sisawa learning outcomes in Thematic learning for Indonesian lessons, $86 \%$ of students have scored above KKM score and $14 \%$ of students got value below KKM score. In Civic Education, $49 \%$ of students have scored above the KKM score and $51 \%$ of students score below the KKM score. In the IPS lesson, $69 \%$ of the students have scored above the KKM score and $31 \%$ of students score below the KKM score. In the science lesson, $57 \%$ of the students had scored above the KKM score and $43 \%$ of the students got the score below the KKM score. While in the Mathematics lesson, $60 \%$ of students have scored above KKM value and $40 \%$ of students got value below KKM score. In addition to the lack of confidence in students express opinions, students sometimes still hesitate in answering questions from teachers, less confident of the ability they have and are reluctant to appear in front of the class. In addition, on the results of interviews with some students, they stated they were embarrassed to appear in front of the class and were afraid of answering the questions posed by the teacher. Based on this, it can be concluded that the majority of student learning outcomes are still below the KKM and students still have low self-efficacy.Based on the problems it takes a model, method or learning strategy that is able to make all students involved in learning activities.

\section{LITERATURE REVIEW}

One alternative that can be done by teachers to overcome the above problems is to apply cooperative learning with Think Pair Share strategy.
Think Pair Share is part of co-operative learning. Cooperative learning is developed from constructivism learning theory developed by Piaget and Vygotsky. From Piaget's first research (Ratna, 1988: 181), it is argued that the knowledge is built into the mind of the child. Piaget and Vygotsky suggest the social nature of a learning process Piaget emphasizes the internal activities of the individual toward the object he faces and the experience that the person has. Vygotsky emphasizes social interaction and constructs knowledge from his social environment. Based on this, the constructivists emphasize the importance of interaction with peers through the formation of study groups, and students are given an active opportunity to express something they think to their friends. Think Pair Share has three stages of activity in its application. The first stage is Think (thinking), at this stage students are given the opportunity to think about something independently, the two Pair (paired), at this stage students in pairs are given the opportunity to discuss what they had thought before, and the third stage Share (share), in this last stage, students in pairs share the results of working with his friends. Think Pair Share learning strategy is perfect if applied to thematic learning. Given the characteristics in thematic learning such as student-centered, direct experience, less obvious splitting of subjects, presenting concepts of various contents, being flexible and using principles while playing. Characteristics of thematic learning match the characteristics of the Think Pair Share Learning Strategy that involves the students taking an active role in the learning activities so that the students get direct experience from the learning activities. Therefore, the implementation of Think Pair Share Learning Strategy in the learning process in the class is expected to be very influential towards the achievement of thematic learning objectives, especially in an effort to improve learning outcomes and self-efficacy.

\section{METHODOLOGY}

This type of research is qualitative with classroom action research design (PTK) conducted in collaboration between grade IV teachers with researchers. The method to be used in this research is the type of classroom action research (PTK) of Kemmis and Mc.Taggart model. PTK Kemmis model and Mc.Taggart essentially consists of four stages in each cycle, namely action planning in the form of learning and simultaneously observation, 
analysis and reflection that can be repeated as a cycle. The study was conducted for 5 months from January to May. This research was conducted at DS Muhammadiyah 12 Pamalang. The subjects receiving the action from this research are the fourth graders Sarid even semester. Data collection methods used in this study include the method of observation, test methods used to obtain data values from students in doing the problem after receiving the action and documentation. Intruments used for the collection of data from the observation sheet, test sheet and questionnaire to measure student selfefficacy. The questionnaire used is the Self-Efficacy Questionnaire for Children (SEQ-C) developed by Peter Muris, the questionnaire has validity and reliability of 0.88 . SEQ-C used Peter Muris in his research entitled "A brief Questionnaire for measuring self-efficacy in youths". In this class action research, the data were analyzed since the learning action was conducted and developed. The data are analyzed by Interactive Miles and Huberman modeling methods that follow steps: 1) Data collection, 2) data reduction, 3) Data presentation, and 4) conclusion or verification. In this research, the application of Think Pair Share learning strategy is considered successful if it can improve some of the following criteria: improving student learning outcomes, improving student selfefficacy, student learning activities, and learning process implementation by applying Think Pair Share learning strategy into $>75 \%$.

\section{RESULT AND DISCUSSION}

In this study, researchers apply Think Pair Share learning strategies to improve learning outcomes and self-efficacy in thematic learning. Think Pair Share (TPS) is a learning technique in cooperative learning first developed by Frank Lyman in 1981. Think Pair Share is a type of cooperative learning designed to influence the pattern of student interaction. This study was conducted in two cycles. Learning outcomes and Self-efficacy on thematic learning from cycle I and cycle II have increased. In the first cycle, the students' scores are as follows:

The implementation of learning in cycle I average score at meeting I for Indonesian is 77,74 and for science is 90,80 with classical learning completeness meeting 1 for Indonesian $64 \%$ and IPA $93,5 \%$. While on the average value at the meeting I for Indonesian is 90.31 and for science is 69.53 with classical learning completeness meeting 2 for Indonesian 90\% and IPA 50\%. Learning outcomes in the table above can be said to have not succeeded. It has not fulfilled the predefined indicator that is student's learning mastery at least $75 \%$ klasikan. At the 2nd meeting there were 16 students who had not yet reached completeness in the science lesson. So it is necessary to improve learning in cycle II.

Based on observation activities on the thematic learning process with Think Pair Share learning strategy seen some aspects that still need to be improved as in the aspect of social self-efficacy that is still a student who picky friend. This is seen from the students reject the group with certain people and do not want to discuss with certain people. In the aspect of academic self-efficacy is the reading activity seen there are still students chatting and drawing, the activities of pairs and share has not run well because it still looks students who do not discuss with their partner and engrossed with his own activities. While on the aspect of emotional self-efficacy of students who are still not convinced with ability and have not been able to control the nervousness. Students were asked for a presentation of students looking very enthusiastic to present their discussion results. However, when they are in front of the class for presentation some students ask their friends to replace him for a presentation.

The teacher activity on learning activity activity by applying cooperative model with Think Pair Share strategy, show that teacher activity is on good category. This is indicated by the percentage of teacher activity at the 1st meeting of $84 \%$ and at the 2 nd meeting by $88 \%$. From both meetings the average gains of $85 \%$. When viewed from the success indicator that is $>75 \%$, then the results of teacher activity can be said successful. From the result of observation of student activity after applying cooperative model with Think Pair Share strategy, students look very enthusiastic in learning achievement which measure student activity during learning show percentage observation result of student activity at meeting 1 equal to $70 \%$ and at meeting 2 equal to $78 \%$. From both meetings, the average is $74 \%$. If seen from success indicator that is $>75 \%$, hence result of student activity can be said not yet succeed. Obstacles that occur in learning 1 and 2 of which occur confusion in students in the implementation of Think Pair Share strategy, some students refuse to work with friends of his group, and less naturally students in doing exercise questions. The above description shows the shortcomings in the first cycle is seen from the results of learning or student and teacher activity.

While in cycle II, obtained the average value at the meeting I for IPS am 89.73 and for IPA are 74.53. Percentage mastery of classical learning meeting 1 for IPS $94 \%$ and Science $74.53 \%$. While at the 2nd meeting the average score for Bahasa 
Indonesia was 94.41 and for PKN were 92.94 Percentage mastery learning classical meeting 2 for Indonesian $97 \%$ and IPA 94\%. Acquisition of learning outcomes has met the criteria of classical provision that is $75 \%$.

From the results of the post-test self-efficacy is done with the instrument in the form of a questionnaire. The result of post test of self-Efficacy of students with the percentage of students with high self-Efficacy category is $90 \%$, students with selfEfficacy category is $10 \%$, while students with low self-Efficacy category is $0 \%$. Based on these data can be stated that there is an increase of $10 \%$ from the previous test results of $80 \%$ to $90 \%$. From the observation of teacher activity on learning process activity by applying cooperative model with Think Pair Share strategy, show that teacher activity is in good category. This is indicated by the percentage of teacher activity at the 1st meeting of $86 \%$ and at the 2 nd meeting of $92 \%$. From both meetings, the average is $89 \%$. When viewed from the success indicator that is $>75 \%$, then the results of teacher activity can be said successful. From the result of observation of student activity after applying cooperative model with Think Pair Share strategy, student looks very enthusiastic in learning of acquisition which measure student activity during learning show percentage observation result of student activity at meeting 1 equal to $76 \%$ and at meeting 2 equal to $84 \%$. From these two meetings the average gains of $80 \%$. If seen from success indicator that is $>75 \%$, hence result of student activity can be told succeeds. Based on the discussion of the research results as described above, the targets set in this study were achieved, ie $75 \%$ of students have achieved learning result completeness, self-efficacy, average student activity included into both categories and teacher activity average in using Think Pair Share learning strategy included into either category. On the basis of these results there is an increase in learning outcomes and self-efficacy grade IV students DS Muhammadiyah 12 Pamulang on thematic learning using the strategy of learning Think Pair Share.

\section{CONCLUSION}

Based on the results of research conducted on the implementation of learning strategies Think Pair Share on thematic learning to improve learning outcomes and self-efficacy fourth grade students SD Mihammadiyah 12 Pamulang menjukkan an increase. This can be seen from the results of data analysts in Cycle I average value at the meeting I for Indonesian is 77.74 and for science is 90.80 and classical learning completeness meeting 1 for Indonesian $64 \%$ and IPA $93.5 \%$ While on the average score at the meeting I for Indonesian is 90.31 and for science is 69.53 with classical learning completeness meeting 2 for Indonesian $90 \%$ and IPA $50 \%$. In Cycle II the average value of meeting I for IPS is 89.73 and for IPA is 74.53 . Percentage mastery of classical learning meeting 1 for IPS $94 \%$ and Science $74.53 \%$. While at the 2nd meeting the average score for Bahasa Indonesia was 94.41 and for PKN was 92.94. Percentage mastery learning classical meeting 2 for Indonesian $97 \%$ and IPA $94 \%$. So obtained the average percentage of learning results completeness in the cycle I $74 \%$ and increased in cycle II by $16 \%$ to $90 \%$. In addition to Self-Efficacy also increased by $10 \%$ of the percentage of pre-test by $80 \%$ to $90 \%$. To teachers who want to improve students' learning outcomes and self-efficacy, start implementing Think Pair Share learning strategies. Because the cool goal of the Think Pair Share learning strategy is to deeply engage students by thinking independently and in groups so that students have the key to their abilities. Implementation of Think Pair Share learning strategy requires good class management, especially in terms of discussion, either in pairs or group discussions. Therefore, more important to learning planning is quite mature. Good time management should also be considered in implementing Think Pair Share learning strategies especially in discussion activities. Giving instruction in learning with Think Pair Share learning strategy should be done clearly, so that students do not experience confusion in learning activities with steps Think Pair Share. For readers interested in researching for further research, whether on the implementation of Think Pair Share learning strategies, as well as on learning outcomes and selfefficacy.

\section{REFERENCES}

Akbar Sa'dun, dkk. (2016) . Implementasi Pembelajaran Tematik di Sekolah Dasar. Bandung: PT Remaja Rosdakarya.

Al-Qur'an, (Bandung: Syaamil Quran, 2009)Q.S. AlBaqarah/2: 286

Bandura, A. (1977). "self-efficacy: Toward a Unifying Theory of Behavioral Change". Psychological $\begin{array}{llll}\text { Review. } & \text { Vol. } & \text { 84. } & \text { No.2. }\end{array}$ http://www.uky.edu/ eushe2/Bandura/Bandura1977 PR.pdf [diakses pada: Sabtu, 17 Desember 2016]

Bandura, A. (1994). "Self-efficacy". Encyclopedia of Human Behavior. Vol. 4 https://www.uky.edu/ ueshe2/Bandura. [diakses pada: Minggu, 01 Januari 2017] 
Dol Sunita M. (2014). “TPS(Think-Pair-Share) : An Active Learning Strategy to Teach Theory of Computation Course". International journal of Education Research and Technologi. Vol. 5 [42014. http://Sougra.com/ijert/ijertdec2014/10.pdf [diakses pada: Kamis, 22 Desember 2016]

Huda, M. (2014). Model-Model Pengajaran dan Pembelajaran. Yogyakarta: Pustaka pelajar.

Jiwa I. W, N. Dantes, A.A.I.N. Marhaeni. (2013). "Pengaruh Implementasi Pembelajaran Tematik Terhadap Prestasi Belajar Ditinjau dari Motivasi Belajar pada Siswa Kelas IV Gugus Empat di Kecamatan Gianyar". jurnal penelitian dan evaluasi pendidikan. vol.3,. http://pasca.undika.ac.id/ejournal/index.php/jurnal_ep/article [diakses pada: sabtu, 31 Desember 2016]

Kunandar. (2014).Penilaian Autentik (Penilaian Hasil Belajar Peserta Didik Berdasarkan Kurikulum 2013). Jakarta: Rajawali Pers.

Kusuma Febrian Widya, Mimin Nur Aisyah. (2012). "Implementasi Model Pembelajaran Kooperatif Tipe Think Pair Share pada Siswa Kelas XI IPS 1 SMA Negeri 2 Wonosari Tahun Ajaran 2011/2012". Jurnal Pendidikan Akuntansi Indonesia. Vol. $\mathrm{X} . \quad$ No. 2. http://jurnal.uny.ac.id/index.php/jpaku/article/view/ 912 [diakses pada: Sabtu, 31 Desember 2016]

Linda Yuspa May. AsmaulKhair. A. Sudirman. (2013). Penerapan Think Pair Share untuk Meningkatkan Aktivitas dan Hasil Belajar IPS. Universitas Lampung.

http://download.portalgaruda.org/article.php [diakses pada: Sabtu, 31 Desember 2016]

Majid, Abdul. (2013). Strategi Pembelajaran. Bandung: PT Remaja Rosdakarya.

MertlerCraig A. (2014). Penelitian Tindakan Kelas. Jakarta:Indeks.

MuhibbinSyah. (2014). PsikologiPendidikan.Bandung: PT RemajaRosdakarya.

Muris, Peter. (2001). "A brief Questionnaire for measuring self-efficacy in youths". Journal of Psychopatology an behavioal Assesment. Vol.23. No.3. 2001. http://link.springer.com/article [diakses pada: Selasa, 03 Januari 2017]

Muris, Peter. (2001) Self-Efficacy Questionnaire for Children http://strinetogether.org/sites/default/files [diakses pada: Selasa, 03 Januari 2017]

NurhasanahUnuy. (2014). Peningkatan Hasil Belajar PKn Melalui Pendekatan Tink Pair Share, UIN Syarif Hidayatullah Jakarta, Tidak dipublikasikan.http://repository.uinjkt.ac.id. [diakses pada: Selasa, 27 Desember 2017]

Ormrod, Jeanne Ellis. (2008). Psikologi pendidikan. Jakarta: Erlangga.

Purwanto. (2016). EvaluasiHasilBelajar. Yogyakarta: PustakaPelajar.

Ratri Nugrahani. (2013). Hubungan Self-efficacy dan Motivasi Belajar dengan Kemandirian Belajar Siswa kelas V SD Negri Se-Kecamatan Danurejan Yogyakarta. Universitas Negri Yogyakarta. 2013. Tidak dipublikasikan. http://eprints.uny.ac.id/16002/1/skripsi\%2520R ATRI [diakses pada: Sabtu, 17 Desember 2016]

Schustac Miriam W, Howard S. Friedman. (2008.) Kepribadian. Jakarta: Erlangga.

Shoimin Aris. (2014). 68 Model Pembelajaran Inovatif dalam Kurikulum 2013. Yogyakarta: Ar-Ruzz Media.

Slameto. (2010). Belajar dan Faktor-faktor yang Mempengaruhinya. Jakarta: RinekaCipta.

Sugiono. (2015). Metode Penelitian Kuantitatif Kualtatif dan $R \& D$. Bandung: Alfabeta.

Sundayana Wachyu. (2014). Pembelajaran Berbasis Tema. Jakarta: Erlangga.

Suprihatiningrum Jamil. (2016.) Strategi Pembelajaran. Jakarta: Ar-Ruzz Media.

SuprijonoAgus. (2015).Cooperative Learning: Teoridan Aplikasi PAIKEM. Yogyakarta: PustakaBelajar.

Usman Abdurrahman Hi. (2015). “Using the TinkPair-Share Strategy to Improve Students' Speaking Ebility at Stain Ternate,Journal of Education and Practice. Vol. 6. No 10".http://files.eric.ed.gov/fulltext/EJ1081679.p df [diakses pada: Selasa, 25 Desember 2016]

Utami Sri Endang. (2015). "Penerapan Strategi Pembelajaran Tematik untuk Meningkatkan Kreativitas dan Hasil Belajar Siswa". Jurnal Paradigma. vol.2. no.1. http://ejournal.kopertais4.or.id/index.php/paradi gma/article [diakses pada: Minggu, 01 Januari 2017]

Utari Unga. I NyomanSudanaDegeng, Sa'dun Akbar. (2016). "Pembelajaran Tematik Berbasis Kearifan Lokal di Sekolah Dasar dalam Menghadapi Masyarakat Ekonomi Asean (MEA)". Jurnal Teori dan Peraktis Pembelajaran IPS. Vol. 1. No. 1. http://journal2.um.ac.id/index.php/jtppips [diakses pada: Sabtu, 31 Desember 2016] 